Int. J. Mol. Sci. 2003, 4, 22-33

International Journal of

Molecular Sciences

ISSN 1422-0067

(C) 2003 by MDPI

www.mdpi.org/ijms/

\title{
Effect of Antioxidant (Turmeric, Turmerin and Curcumin) on Human Immunodeficiency Virus
}

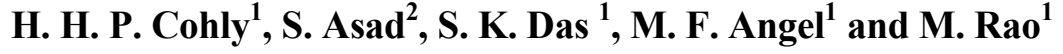 \\ ${ }^{1}$ Department of Surgery, University of Mississippi Medical Center, Jackson, MS, USA, 39216-4505, \\ E-mail: hcohly@surgery.umsmed.edu \\ ${ }^{2}$ Faculty of Medicine and Division of Infectious Diseases, The Hospital for Sick Children and \\ University of Toronto, Toronto, Canada, M5G 1X8.
}

Received: 7 June 2002 / Accepted: 30 October 2002 / Published: 31 January 2003

\begin{abstract}
Oxidative stress is implicated in HIV-infection. It has been suggested that plant antioxidants may offer protection from viral replication and cell death associated with oxidative stress in patients with HIV/AIDS. Because of inherent antioxidant properties of turmeric (T) and its derivatives, water-soluble extract turmerin (Tm) and lipid soluble curcumin $(\mathrm{Cu})$, their potential efficacy as anti-HIV drugs were examined. Cell viability and p-24 antigen release by CEMss-T cells $\left(1 \times 10^{5}\right.$ cells $\left./ \mathrm{ml}\right)$ infected with HIV-III ${ }_{B}$ strain, used as an acute model of infection, were tested in the presence of 3'azido-3'deoxythmidine (AZT). Proliferative responses of human mononuclear cells derived from HIV patients (chronic model) stimulated with phyohemagglutinin (PHA), concanavalin A (ConA), and pokeweed mitogen (PWM) were also examined in the presence of AZT and Tm. In the infection assay, $\mathrm{T}, \mathrm{Tm}$ and $\mathrm{Cu}$ individually did not reduce p-24 antigen release or improve cell viability. AZT $(5 \mu \mathrm{M})+\mathrm{Tm}(800 \mathrm{ng} / \mathrm{ml})$ inhibited infection by $37 \%$ and increased cell numbers by $30 \%$; whereas, Tm $(80 \mathrm{ng} / \mathrm{ml})$ inhibited infection by $26 \%$ and increased cell number by $60 \%$. In the proliferation assay, lymphocytes from HIV-infected patients showed better inhibition of mitogen responsiveness to $\mathrm{Tm}(800 \mathrm{ng} / \mathrm{ml})$ when compared to AZT at $5 \mu \mathrm{M}$ or Tm at $80 \mathrm{ng} / \mathrm{ml}$. Turmerin inhibited HIV-infected T-cell proliferation and, in combination with AZT, decreased T-cell infection and increased cell viability. These data provide evidence suggesting that efficacious anti-HIV therapy may be possible using lower, less toxic doses of AZT in the presence of turmerin.
\end{abstract}

Keywords: Turmeric, turmerin, curcumin, p-24 antigen, proliferation. 


\section{Introduction}

Turmeric (T) is a yellow powder, derived from the plant Curcuma longa. It has been consumed in amounts up to one g/day for thousands of years in countries such as India. Previous pharmacological studies have demonstrated its anti-tumor, anti-inflammatory, anti-infectious and antioxidant activity with very low toxicity [1-4]. Turmeric consists of a water-soluble component, turmerin (Tm; mol weight 24,000 daltons), and lipid-soluble component Curcumin ( $\mathrm{Cu}$; mol weight 369.89 daltons). Curcumin (diferuloylmethane), the yellow pigments in $\mathrm{T}$ that is widely used as a food coloring (curry) and preservative has been extensively studied. In particular, $\mathrm{Cu}$ inhibited purified human immunodeficiency virus type 1 (HIV-1) integrase [5, 6], HIV-1 and HIV-2 proteases [7], and HIV-1 long terminal repeat directed gene expression of acutely or chronically infected HIV-1 cells [8]. $\mathrm{Cu}$ also inhibited lipopolysaccharide (LPS)-induced activation of nuclear factor kappa B, a factor involved in the activation and replication of HIV-1 [9]. However, $\mathrm{Cu}$ has been tested in clinical trials with not much success [10]. Whereas much investigation has focused on $\mathrm{Cu}$, the anti-HIV activity of $\mathrm{T}$ and $\mathrm{Tm}$ has not been well characterized to date.

Oxidative stress (OS) may play a role in viral replication, decreased immune cell proliferation, and increased sensitivity to drug toxicity. An increase in free radical production and lipid peroxidation has also been described in HIV infected patients [11, 12]. During HIV-infection, free radical damage may be produced, not only by a direct production of oxygen radicals by phagocytes, but also by a tumor necrosis factor (TNF)-mediated generation in target cells. Antioxidants have demonstrated protective capacity for TNF cytotoxicity. TNF-induced free radicals can increase the replication of HIV-1 and destroy T-cells [13]. The superoxide $\left(\mathrm{O}_{2}{ }^{-}\right)$significantly enhanced cell-to-cell transmission of HIV-1 [14]. Evidence has accumulated suggesting that HIV-infected patients are under chronic OS [15]. A redox imbalance caused by an over-production of pro-oxidants or a decrease in antioxidants seems to play an important role in the normal physiological function. Following activation, lymphocytes produced increased levels of OS. Lymphocytes from such individuals were more prone to undergo apoptosis or cell death in-vitro [16]. Antioxidant supplementation significantly improved some measures of oxidative defense [17]. Thus, using antioxidants may be an alternate means of treating HIV-patients.

The anti-retroviral drug AZT is a dideoxynucleoside analog which, upon activation by the target cell, reduces viral infectivity and enhances immune functions in HIV-infected patients [18]. It inhibits retroviral reverse transcriptase as well as cellular DNA polymerase $\beta$ and $\gamma[19,20]$. AZT delays disease progression in HIV-infected patients but cause unpredictable side effects [21,22]. Ideally, reduction in AZT dosage requirements through combination with some other pharmacologically-active agent would lessen toxicity while maintaining viral inhibition. In addition, combination therapy facilitates drug synergism and delay development of resistance [23-25].

The rationale for testing turmeric and its derivatives was based on their potent antioxidant properties and their potential use as an adjuvant to AZT as modulators of OS. Previously, we have shown that T and 
$\mathrm{Cu}$ protect kidney epithelial cells from $\mathrm{H}_{2} \mathrm{O}_{2}$-induced injury while Tm had no protective effect [26]. In the present study, we have shown that $\mathrm{Tm}(800 \mathrm{ng} / \mathrm{ml})$ in combination with AZT $(\mu \mathrm{M})$ maximally inhibited HIV-infection in CEM-T cell-line model and $\mathrm{Tm}(800 \mathrm{ng} / \mathrm{ml})$ maximally inhibited the activation of HIV-infected human mononuclear cells to T or B cell mitogens. Whether consumption of exogenous plant antioxidants [27] like T, $\mathrm{Cu}$ and $\mathrm{Tm}$ can be useful in inhibiting viral activation and the death of immune cells in HIV/AIDS through their antioxidant properties is not addressed in this study and will certainly warrant further investigation.

\section{Materials and Methods}

Anti-retroviral Nucleosides

AZT was purchased from Wellcome Beckenham (Kent, UK) and re-suspended in sterile distilled water as stock solutions and serially diluted before experiments. Concentration of AZT added was $5 \mu \mathrm{M}$.

\section{$T, T m$ and $C u$}

Turmeric powder was obtained from Raja Foods (Lincolnwood, IL). Curcumin was obtained from Aldrich Chemicals (St Louis, MO). Turmerin was obtained by boiling 1\% turmeric solution for 30 minutes, centrifuging at $1200 \mathrm{x}$ g for 10 minutes and passing the supernatant through $0.22 \mu$ filter. The protein yield of the filtered solution was $80 \mu \mathrm{g} / \mathrm{ml}$.

\section{Study Population}

For the present study, blood was obtained from 10 HIV-1 seropositive participants.

\section{Lymphocyte Preparation (Chronic T-cell model of HIV infection)}

Fresh peripheral blood mononuclear cells (PBMC) were obtained from HIV-1 seropositive subjects (positive p-24), the blood was diluted 1:1 with sterile phosphate buffered saline (PBS), underlayed with lymphocyte separation medium (LSM, Oreganon, Teknika, West Chester, PA). The sample was centrifuged at $800 \mathrm{Xg}$ for 25 minutes, the PBMC layer was removed and washed twice with PBS, and the cell pellet was resuspended in medium 1640. These cells were cultured in round-bottomed, 96well plates (Falcon) in RPMI 1640 medium (Gibco) with 10\% human AB serum and antibiotics (100 units $/ \mathrm{ml}$ penicillin, $100 \mathrm{mg} / \mathrm{ml}$ streptomycin) at a concentration of $1 \times 10^{6}$ cells $/ \mathrm{ml}$ (viability $\geq 95 \%$ ) with each well receiving $100 \mu \mathrm{l}$ of the cells. Cells were incubated with media alone or with final $20 \mu \mathrm{g} / \mathrm{ml}$ phytohemagglutinin (PHA), $10 \mu \mathrm{g} / \mathrm{ml}$ Concanavalin A (Con A) or $1 \mathrm{ng} / \mathrm{ml}$ Pokeweed mitogen (PWM) (Sigma). In the first three wells, cells were incubated with $100 \mu 1$ of media serving as media controls. In the subsequent wells the plates were incubated with 1) $100 \mu 1$ of mitogen (mitogen controls), 2) $100 \mu \mathrm{l}$ of mitogen $+10 \mu \mathrm{l}$ of Tm (800ng/ml), 3) $100 \mu \mathrm{l}$ of mitogen $+10 \mu 1$ of Tm (80ng/ml). 4) $100 \mu 1$ of 
mitogen $+10 \mu 1$ of AZT $(5 \mu \mathrm{M})$. The controls for AZT, Tm $(800 \mathrm{ng} / \mathrm{ml})$ and Tm $(80 \mathrm{ng} / \mathrm{ml})$ were cells that only had the drug with no mitogen. All lymphocyte proliferation assays were done in triplicate in 5\% $\mathrm{CO}_{2}$. After 3 days of incubation at $37^{\circ} \mathrm{C}$, the cells were labeled with $20 \mu \mathrm{Ci} / \mathrm{ml}(25 \mu 1 /$ well $)$ of $3[\mathrm{H}]$ thymidine (specific activity $5 \mathrm{mM}$ Radiochemical Inc, Amersham, USA) in RPMI. Cells were harvested (PHD cell harvester Brandel, Inc.) and incorporated label was determined by scintillation counting. The results were expressed as mean counts per minute $(\mathrm{cpm}) \pm \mathrm{SD}$.

\section{Virus}

HIV-1 was obtained from the culture supernatant of HTLV-III $\mathrm{B}_{\mathrm{B}}$-producing H9 cells. During the exponential phase of growth, cell-free supernatant was harvested, standardized for reverse transcriptase activity, and frozen in aliquots at $-70^{\circ} \mathrm{C}$.

\section{CEM preparation (Acute T-cell model of HIV infection)}

A human non-adherent CD4+ T cell line, CEM-ss cells were obtained from (NIH AIDS Research and

Reference Reagent Program) and $5 \times 10^{5}$ cells were infected with HTLV-III ${ }_{B}$ (1 reverse transcriptase unit $/ 10$ cells) at $37^{\circ} \mathrm{C}$ for $2 \mathrm{hrs}$. Non-adsorbed virus was then removed by washing 3 times with phosphate buffered saline. Cells were cultured on a 24-plate and incubated in the presence and absence of drugs. Cells were incubated with $100 \mu \mathrm{l}$ of Turmeric $(100 \mu \mathrm{g} / \mathrm{ml}$ or $10 \mu \mathrm{g} / \mathrm{ml})$, Curcumin $(100 \mu \mathrm{g} / \mathrm{ml}$ or $10 \mu \mathrm{g} / \mathrm{ml})$, or Turmerin $(800 \mathrm{ng} / \mathrm{ml}$ or $80 \mathrm{ng} / \mathrm{ml})$. HIV-1 production was monitored at 3- and 7-day time intervals by measuring the level of p-24 antigen ( $24 \mathrm{kDa} \mathrm{HIV}-1$ gag gene product) in culture supernatants. The culture supernatant was tested for the presence of HIV-1 p24 antigen, using the HIV AGA enzyme immunoassay kit from Abbott Laboratories (Abott Park, IL) according to manufacturer instructions. A standard curve (Optical Density at 492nm as a function of p24 antigen concentration) was obtained using p24 antigen provided by the supplier. An optical density value of 1 corresponds to 200 pgs of HIV-1 p-24 antigen. All our results had a cut-off value of 0.1 optical density (OD) units. These experiments were repeated at least twice. After 7 days, cell viability and cell number was determined by the trypan blue exclusion method.

\section{Results}

\section{Selective inhibition of p-24 antigen and increased cell viability by turmerin}

CD4+-T-cell line infected with HTLV-III ${ }_{B}$ strain was used to study inhibition of HIV infectivity. Cells exposed to $\mathrm{T}(100 \mu \mathrm{g} / \mathrm{ml}$ or $10 \mu \mathrm{g} / \mathrm{ml}), \mathrm{Cu}(100 \mu \mathrm{g} / \mathrm{ml}$ or $10 \mu \mathrm{g} / \mathrm{ml})$ or $\mathrm{Tm}(800 \mathrm{ng} / \mathrm{ml}$ or $80 \mathrm{ng} / \mathrm{ml})$ alone or in combination with AZT were tested for p24 antigen production (Table 1) and cell viability was determined (Table 2). 
Table 1. Percentage increase or decrease of infection ( $\mathrm{p}-24$ antigen release)

\begin{tabular}{lcc}
\hline Drug Treatment & $(-)$ AZT & $(+)$ AZT \\
\hline $\mathrm{T}(100 \mu \mathrm{g} / \mathrm{ml})$ & 5.2 & 21.1 \\
$\mathrm{~T}(10 \mu \mathrm{g} / \mathrm{ml})$ & 201.7 & 10.5 \\
$\mathrm{Cu}(100 \mu \mathrm{g} / \mathrm{ml})$ & 46.6 & 63.2 \\
$\mathrm{Cu}(10 \mu \mathrm{g} / \mathrm{ml})$ & 184.5 & 5.3 \\
$\mathrm{Tm}(800 \mathrm{ng} / \mathrm{ml})$ & 63.8 & -36.8 \\
$\mathrm{Tm}(80 \mathrm{ng} / \mathrm{ml})$ & 115.5 & -26.3 \\
\hline \% increase in infection $=100 \mathrm{x}([\mathrm{T} / \mathrm{Cu} / \mathrm{Tm}$ treatment OD minus Control OD $]) /($ Control OD) & where the Control OD is the \\
Optical density of the cells with media alone $(100 \%)$. &
\end{tabular}

Table 2. Percentage increase or decrease in viability from control (Trypan Blue exclusion)

\begin{tabular}{lcc}
\hline Drug Treatment & $(-)$ AZT & $(+)$ AZT \\
\hline $\mathrm{T}(100 \mu \mathrm{g} / \mathrm{ml})$ & -50.0 & -20.0 \\
$\mathrm{~T}(10 \mu \mathrm{g} / \mathrm{ml})$ & -38.9 & 50.0 \\
$\mathrm{Cu}(100 \mu \mathrm{g} / \mathrm{ml})$ & -22.2 & -10.0 \\
$\mathrm{Cu}(10 \mu \mathrm{g} / \mathrm{ml})$ & -11.1 & 50.0 \\
$\mathrm{Tm}(800 \mathrm{ng} / \mathrm{ml})$ & -11.1 & 30.0 \\
$\mathrm{Tm}(80 \mathrm{ng} / \mathrm{ml})$ & -16.7 & 60.0 \\
\hline
\end{tabular}

$\%$ increase in viability $=100 \times[(\mathrm{T} / \mathrm{Cu} / \mathrm{Tm}$ treatment cell number minus Control cell number $]) /($ Control cell number $)$ is where the control cell number is the cell number with media alone (100\%).

Turmeric $(100 \mu \mathrm{g} / \mathrm{ml})$, the parent compound, had the lowest percentage increase for infection (5.2\%) in the absence of AZT while AZT $+\mathrm{Tm}(800 \mathrm{ng} / \mathrm{ml})$ showed the lowest percentage increase for infection which corresponds to an inhibition of $36.8 \%$ (Table 1). With respect to viability, $\mathrm{T}(800 \mathrm{ng} / \mathrm{ml})$ and $\mathrm{Cu}$ $(10 \mu \mathrm{g} / \mathrm{ml})$ showed the highest percentage increase for viability which corresponds to an inhibition of $11.1 \%$ in the absence of AZT while $\mathrm{Tm}(80 \mathrm{ng} / \mathrm{ml})$ showed highest percentage increase for viability $(60 \%)$ in the presence of AZT (Table 2).

\section{Proliferative response of PHA, Con A, PWM activated HIV-infected Human PBMC}

Table 3 is the compilation of proliferative response of PHA, Con A and PWM in HIV-infected human PBMC data from ten patients. Figure 1 is an example of data from patient 1 showing that AZT or Tm at $800 \mathrm{ng} / \mathrm{ml}$ and $80 \mathrm{ng} / \mathrm{ml}$ inhibited proliferation when compared to cells treated alone with $\mathrm{T}$ cell mitogens PHA and Con A or B cell mitogen PWM. Tm $800 \mathrm{ng} / \mathrm{ml}$ showed maximum inhibition of proliferation when compared to AZT or Tm .In particular for patient \#1, stimulation index (ratio of cpm of stimulated cells versus cpm of unstimulated cells [media control]) for Tm $800 \mathrm{ng} / \mathrm{ml}+$ PHA was 16.6, for Tm 800 $\mathrm{ng} / \mathrm{ml}+$ Con A was 2.3 and for $\mathrm{Tm} 800 \mathrm{ng} / \mathrm{ml}+\mathrm{PWM}$ was 3.8. A trypan blue exclusion assay showing 
Table 3a. Total CPM (Mean \pm SD) in PBMC of HIV + patients treated with PHA.

\begin{tabular}{llllll}
\hline Pt\# & \multicolumn{1}{c}{ Media } & \multicolumn{1}{c}{ PHA } & PHA+AZT $5 \mu \mathrm{M}$ & PHA+Tm80ng/ml & PHA+Tm 800ng/ml \\
\hline 1 & $1,048 \pm 69$ & $58,377 \pm 6,534$ & $30,373 \pm 561$ & $40,388 \pm 6,041$ & $17,431 \pm 870$ \\
2 & $235 \pm 98$ & $28,727 \pm 1,815$ & $15,050 \pm 3,597$ & $32,170 \pm 1,496$ & N.D. \\
3 & $1,603 \pm 417$ & $323,061 \pm 43,362$ & $229,133 \pm 11,376$ & $367,124 \pm 35,117$ & N.D. \\
4 & $1,307 \pm 313$ & $44,758 \pm 9,154$ & $33,552 \pm 4,370$ & $41,579 \pm 4,969$ & $25,476 \pm 3,745$ \\
5 & $474 \pm 140$ & $284,041 \pm 12,721$ & N.D. & $129,729 \pm 2,465$ & $22,643 \pm 3,754$ \\
6 & $973 \pm 152$ & $56,5021 \pm 1,602$ & N.D. & $227,385 \pm 16,031$ & $30,503 \pm 5,964$ \\
7 & $847 \pm 190$ & $43,725 \pm 3,197$ & N.D. & $38,530 \pm 2,443$ & $1,218 \pm 130$ \\
8 & $767 \pm 92$ & $28,988 \pm 97$ & N.D. & $26,305 \pm 1,206$ & $2,245 \pm 655$ \\
9 & $1,690 \pm 615$ & $24,191 \pm 394$ & N.D. & $20,145 \pm 470$ & $3,612 \pm 970$ \\
10 & $1,422 \pm 64$ & $59,369 \pm 971$ & N.D. & $46,999 \pm 2,112$ & $3,207 \pm 390$ \\
\hline
\end{tabular}

Table 3b. Total CPM (mean $\pm \mathrm{SD}$ ) in $\mathrm{PBMC}$ of $\mathrm{HIV}+$ patients treated with Con $\mathrm{A}$.

\begin{tabular}{llllll}
\hline Pt\# & \multicolumn{1}{c}{ Media } & \multicolumn{1}{c}{ Con A } & Con A+AZT 5 $\mu \mathrm{M}$ & Con A+Tm80ng/ml & Con A+Tm 800ng/ml \\
\hline 1 & $1,048 \pm 69$ & $24,962 \pm 1,286$ & $8,849 \pm 833$ & $7,862 \pm 1,584$ & $2,364 \pm 305$ \\
2 & $235 \pm 98$ & $1,099 \pm 747$ & $499 \pm 101$ & $233 \pm 120$ & N.D. \\
3 & $1,603 \pm 417$ & $261,903 \pm 16,282$ & $145,582 \pm 7,796$ & $147,782 \pm 1,759$ & N.D. \\
4 & $1,307 \pm 313$ & $25,130 \pm 148$ & $17,163 \pm 5,742$ & $15,157 \pm 4,345$ & $5,530 \pm 1,192$ \\
5 & $474 \pm 140$ & $132,930 \pm 16,300$ & N.D. & $37,777 \pm 6,429$ & $9,530 \pm 1,198$ \\
6 & $973 \pm 152$ & $265,056 \pm 26,172$ & N.D. & $130,535 \pm 20,361$ & $29,437 \pm 11,618$ \\
7 & $847 \pm 190$ & $26,001 \pm 2,772$ & N.D. & $17,535 \pm 2,736$ & $372 \pm 72$ \\
8 & $767 \pm 92$ & $14,638 \pm 154$ & N.D. & $12,244 \pm 165$ & $1,560 \pm 599$ \\
9 & $1,690 \pm 615$ & $8,236 \pm 54$ & N.D. & $7,463 \pm 1,171$ & $3,714 \pm 552$ \\
10 & $1,422 \pm 64$ & $20,456 \pm 1,120$ & N.D. & $14,164 \pm 1,654$ & $1,921 \pm 471$ \\
\hline
\end{tabular}

Table 3c. Total CPM (mean \pm SD) in PBMC of HIV + patients treated with PWM.

\begin{tabular}{llllll}
\hline Pt\# & \multicolumn{1}{c}{ Media } & \multicolumn{1}{c}{ PWM } & PWM+AZT $5 \mu \mathrm{M}$ & PWM+Tm80ng/ml & PWM+Tm 800ng/ml \\
\hline 1 & $1,048 \pm 69$ & $12,056 \pm 276$ & $5,851 \pm 1,203$ & $10,427 \pm 3,763$ & $3,967 \pm 663$ \\
2 & $235 \pm 98$ & $4,503 \pm 1,365$ & $2,396 \pm 538$ & $4,886 \pm 654$ & N.D. \\
3 & $1,603 \pm 417$ & $82,535 \pm 18,509$ & $50,016 \pm 8,365$ & $72,954 \pm 6,993$ & N.D. \\
4 & $1,307 \pm 313$ & $14,148 \pm 5,056$ & $9,795 \pm 1,322$ & $15,485 \pm 1,544$ & $9,736 \pm 624$ \\
5 & $474 \pm 140$ & $123,251 \pm 2,597$ & N.D. & $63,382 \pm 6,358$ & $11,847 \pm 1,809$ \\
6 & $973 \pm 152$ & $202,760 \pm 21,170$ & N.D. & $81,732 \pm 2,815$ & $4,816 \pm 192$ \\
7 & $847 \pm 190$ & $22,593 \pm 3,419$ & N.D. & $17,625 \pm 992$ & $14,529 \pm 884$ \\
8 & $767 \pm 92$ & $5,166 \pm 165$ & N.D. & $4,772 \pm 259$ & $1,361 \pm 83$ \\
9 & $1,690 \pm 615$ & $3,662 \pm 187$ & N.D. & $4,816 \pm 192$ & $3,454 \pm 600$ \\
10 & $1,422 \pm 64$ & $16,382 \pm 694$ & N.D. & $14,529 \pm 884$ & $1,376 \pm 260$ \\
\hline
\end{tabular}




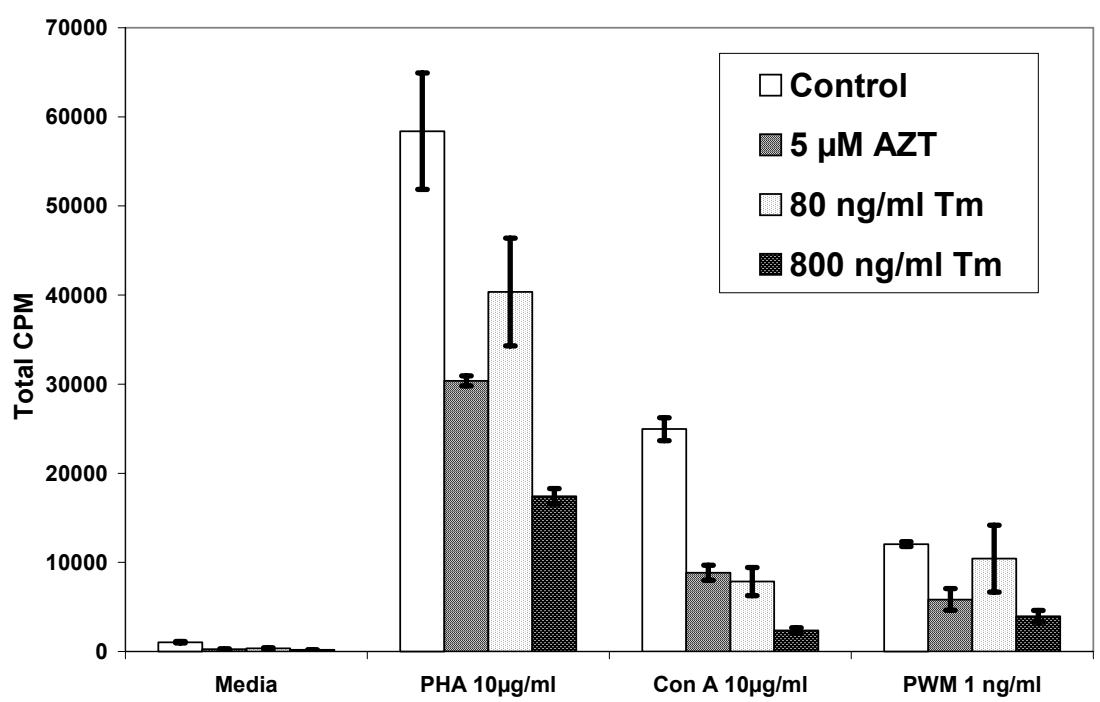

Figure 1. Comparison of peripheral blood mononuclear cells isolated from HIV + patient and incubated with PHA, Con A and PWM in combination with Tm $(800 \mathrm{ng} / \mathrm{ml} ; 80 \mathrm{ng} / \mathrm{ml})$ or AZT $(5 \mu \mathrm{M})$ for $72 \mathrm{hrs}$. The cells were pulsed with radiolabeled thymidine for $18 \mathrm{hrs}$ and then harvested for counting by liquid scintillation. Responses are expressed as net cpm and dose of drug is expressed as $\mathrm{ng} / \mathrm{ml}$ and $\mu \mathrm{g} / \mathrm{ml}$. Values represent the mean of at least triplicate readings and the standard deviation (S.D.).

similar viability in drug-exposed and control cultures (data not shown) confirmed that inhibition by Tm did not depend on generalized drug toxicity

\section{Discussion}

Loss or reduction of T-cell proliferative capacity to in-vitro stimulation is one of the qualitative changes observed in the functional performance of PBMC from HIV-infected subjects [28-34]. T-cell proliferative capacity is an important independent predictor of progression to HIV disease [35, 36] and can also serve to monitor immunological improvement after therapy [37,38]. Decreased proliferation of T-cells from HIV-infected individuals has been previously measured in response to in-vitro stimulation with CD3 monoclonal antibody, pokeweed mitogen, alloantigens, and recall antigens [3943]. The response to phytohemagglutinin (PHA) remains unaffected in the early phases but is significantly reduced later in infection [44, 45]. In our series, there was high proliferation to PHA. This implies that the patients we are dealing with are in the early phases of HIV-infection.

The mechanism of action of turmeric and turmerin on HIV infection has yet to be determined. The inhibition of mitogen stimulated PBMC and CEM-ss cells suggest that the drug treatment is critical to the virus infected chronic $\mathrm{T}$ cell infection as well as to the virus adsorbed acute $\mathrm{T}$ cell infection. That $\mathrm{T}$ and $\mathrm{Cu}$ inhibit virus adsorbed acutely infected CEM-ss $\mathrm{T}$ cells at fairly high concentrations while a low dose 
of Tm would suffice suggests that the bulk of ingested drug as a treatment therapy with Tm will be less than with $\mathrm{T}$ and $\mathrm{Cu}$.

Our results in HIV-infection studies exhibited a clear advantage of using $\mathrm{Tm}$ at $800 \mathrm{ng} / \mathrm{ml} \mathrm{in}$ combination with AZT to maximally decrease the infection when compared to turmeric and curcumin. The viability results showed that $\mathrm{Tm}$ at $80 \mathrm{ng} / \mathrm{ml}$ maximally increases viability when compared with turmeric and curcumin. The interesting point to note is that the higher concentration of $\mathrm{Tm} 800 \mathrm{ng} / \mathrm{ml}$ increases viability only by $30 \%$ when compared with $60 \%$ with $\mathrm{Tm}$ at $80 \mathrm{ng} / \mathrm{ml}$ indicating that higher concentrations of turmerin may be toxic. With respect to mitogen proliferation (patient 1 and Figure 1), it is clear that Tm maximally inhibited proliferation for PHA, Con A and PWM as noted by decreased stimulation indices. $T$ cell proliferation data clearly shows that in $8 / 10$ patients $\mathrm{Tm}$ at $800 \mathrm{ng} / \mathrm{ml}$ and 80 $\mathrm{ng} / \mathrm{ml}$ or AZT individually inhibit proliferation of mitogen stimulated cells. Two out of ten patients (\#2 and \#3) show that Tm is not inhibiting PHA stimulation. In addition, Tm in patient \# 2 is not inhibiting PWM stimulation. Inhibition of mitogen proliferation of some patient cells is not inhibited in the presence of Tm alone suggests that Tm lacks the effectiveness in preventing infected T cell proliferation.

T-cell activation is known to be required for the induction of HIV mRNA transcription, viral replication, and spread of infection to newly activated CD4 $+\mathrm{T}$ cells [46]. This implies that by downmodulating mitogen responsiveness, AZT used alone or in combination with turmerin could confer an unresponsive status to the HIV-infected T-cells, thereby decreasing capacity for viral replication. If so, AZT in combination with Tm could hypothetically inhibit the increases in the viral load and inhibit infection of virgin cells - a worthwhile achievement in the treatment of asymptomatic $\mathrm{HIV}+$ patients in whom viral spread has not occurred. Also, our proliferation data shows that turmerin will not be effective in a cohort of patients because it did not reduce T-cell proliferation.

These findings provide evidence that toxicity of AZT may be reduced by virtue of being able to use lower doses of the drug in combination with turmerin. Additional work is in progress to determine the optimum dosage at which AZT concentration can be decreased in combination with turmerin to reduce its toxicity.

\section{Acknowledgements}

We thank Cindy Lovell for editing the manuscript.

\section{References}

1. Shalini, V. K.; Srinivas, L. Lipid peroxide-induced DNA damage: protection by turmeric (Curcuma longa). Mol. Cell. Biochem. 1987, 77, 3-10.

2. Shalini, V. K.; Srinivas, L. Fuel smoke condensate-induced DNA damage in human lymphocytes and protection by turmeric (Curcuma longa). Mol. Cell. Biochem. 1990, 95, 21-30. 
3. Srinivas, L.; Shalini, V. K.; Shylaja, M. Turmerin: a water soluble antioxidant peptide from turmeric [Curcuma longa]. Arch. Biochem. Biophys. 1992, 292, 617-623.

4. Srinivas, L.; Shalini, V. K. DNA damage by smoke: protection by turmeric and other inhibitors of ROS. Free Radic. Biol. Med. 1991, 11, 277-283.

5. Mazumder, A.; Raghavan, K.; Weinstein, J.; Kohn, K. W.; Pommier, Y. Inhibition of human immunodeficiency virus type-1 integrase by curcumin. Biochem. Pharm. 1995, 49, 1165-1170.

6. Burke, T. R. Jr.; Fesen, M. R.; Mazumder, A.; Wang, J.; Carothers, A. M.; Grunberger, D.; Driscoll, J.; Kohn, K.; Pommier, Y. Hydroxylated aromatic inhibitors of HIV-1 integrase. J. Med. Chem. 1995, 38, 4171-4178.

7. Sui, Z.; Salto, R.; Li, J.; Craik, C.; Ortiz de Montellano, P. R. Inhibition of the HIV-1 and HIV-2 proteases by curcumin and curcumin boron complexes. Bioorg. Med. Chem. 1993, 1, 415-422.

8. Li, C. J.; Zhang, L. J.; Dezube, B. J.; Crumpacker, C. S.; Pardee, A. B. Three inhibitors of type 1 human immunodeficiency virus long terminal repeat-directed gene expression and virus replication. Proc. Natl. Acad. Sci. U. S. A. 1993, 90, 1839-1842.

9. Chan, M. M. Inhibition of tumor necrosis factor by curcumin, a phytochemical. Biochem. Pharm. 1995, 49, 1551-1556.

10. James, J. S. Curcumin: clinical trial finds no antiviral effect. AIDS Treat. News 1996, 1 (no 242), 12.

11. Favier, A.; Sappey, C.; Leclerc, P.; Faure, P.; Micoud, M. Antioxidant status and lipid peroxidation in patients infected with HIV. Chem.-Biol. Interact. 1994, 91, 165-180.

12. Jaruga, P.; Jaruga, B.; Gackowski, D.; Olczak, A.; Halota, W.; Pawlowska, M.; Olinski, R. Supplementation with antioxidant vitamins prevents oxidative modification of DNA in lymphocytes of HIV-infected patients. Free Radic. Biol. Med. 2002, 32, 414-420.

13. Ferlat, S.; Favier, A. [Tumor necrosis factor (TNF) and oxygen free radicals: potential effects for immunity]. C. R. Sean. Soc. Biol. Fil. 1993, 187, 296-307.

14. Kameoka, M.; Kimura, T.; Ikuta, K. Superoxide enhances the spread of HIV-1 infection by cell-tocell transmission. FEBS Lett. 1993, 331, 182-186.

15. Pace, G. W.; Leaf, C. D. The role of oxidative stress in HIV disease. Free Radic. Biol. Med. 1995, $19,523-528$.

16. Buttke, T. M.; Sandstrom, P. A. Redox regulation of programmed cell death in lymphocytes. Free Radic. Res. 1995, 22, 389-397.

17. Batterham, M.; Gold, J.; Naidoo, D.; Lux, O.; Sadler, S.; Bridle, S.; Ewing, M.; Oliver, C. A. Preliminary open label dose comparison using an antioxidant regimen to determine the effect on viral load and oxidative stress in men with HIV/AIDS. Eur. J. Clin. Nutr. 2001, 55, 107-114.

18. Skowron, G.; Merigan, T. C. Alternating and intermittent regimens of zidovudine (3'-azido-3'deoxythymidine) and dideoxycytidine (2',3'-dideoxycytidine) in the treatment of patients with acquired immunodeficiency syndrome (AIDS) and AIDS-related complex. Am. J. Med. 1990, 88, 20S-23S. 
19. Furmanski, P.; Bourguignon, G. J.; Bolles, C. S.; Corombos, J. D.; Das, M. R. Inhibition by 2',3'dideoxythymidine of retroviral infection of mouse and human cells. Cancer Lett. 1980, 8, 307315.

20. Faras, A. J.; Taylor, J. M.; Levinson, W. E.; Goodman, H. M.; Bishop, J.M. RNA-directed DNA polymerase of Rous sarcoma virus: initiation of synthesis with $70 \mathrm{~S}$ viral RNA as template. $J$. Mol. Biol. 1973, 79, 163-183.

21. Richman, D. D.; Andrews, J. Results of continued monitoring of participants in the placebocontrolled trial of zidovudine for serious human immunodeficiency virus infection. Am. J. Med. 1988, 85, 208-213.

22. Merigan, T. C.; Skowron, G.; Bozzette, S. A.; Richman, D.; Uttamchandani, R.; Fischl, M.; Schooley, R.; Hirsch, M.; Soo, W.; Pettinelli, C.; et al. Circulating p24 antigen levels and responses to dideoxycytidine in human immunodeficiency virus (HIV) infections. A phase I and II study. Ann. Intern. Med. 1989, 110, 189-194.

23. Fischl, M. A.; Parker, C. B.; Pettinelli, C.; Wulfsohn, M.; Hirsch, M. S.; Collier, A. C.; Antoniskis, D.; Ho, M.; Richman, D. D.; Fuchs, E.; et al. A randomized controlled trial of a reduced daily dose of zidovudine in patients with the acquired immunodeficiency syndrome. The AIDS Clinical Trials Group. N. Engl. J. Med. 1990, 323, 1009-1014.

24. Eron, J. J. Jr.; Johnson, V. A.; Merrill, D. P.; Chou, T. C.; Hirsch, M. S. Synergistic inhibition of replication of human immunodeficiency virus type 1, including that of a zidovudine-resistant isolate, by zidovudine and 2',3'-dideoxycytidine in-vitro. Antimicrob. Agents Chemother. 1992, $36,1559-1562$.

25. Meng, T. C.; Fischl, M. A.; Boota, A. M.; Spector, S. A.; Bennett, D.; Bassiakos, Y.; Lai, S. H.; Wright, B.; Richman, D. D. Combination therapy with zidovudine and dideoxycytidine in patients with advanced human immunodeficiency virus infection. A phase I/II study. Ann. Intern. Med. 1992, 116, 13-20.

26. Cohly, H. H.P.; Taylor, A.; Angel, M. F.; Salahudeen, A. K. Effect of turmeric, turmerin and curcumin on H2O2-induced renal epithelial (LLC-PK1) cell injury. Free Radic. Biol. Med. 1998, $24,49-54$.

27. Greenspan, H. C.; Aruoma, O. I. Could oxidative stress initiate programmed cell death in HIV infection? A role for plant derived metabolites having synergistic antioxidant activity. Chem.-Biol. Interact. 1994, 91, 187-197.

28. Lane, H. C.; Depper, J. M.; Greene, W. C.; Whalen, G.; Waldmann, T. A.; Fauci, A. S. Qualitative analysis of immune function in patients with the acquired immunodeficiency syndrome. Evidence for a selective defect in soluble antigen recognition. N. Engl. J. Med. 1985, 313, 79-84.

29. Bentin, J.; Tsoukas, C. D.; McCutchan, J. A.; Spector, S. A.; Richman, D. D.; Vaughan, J.H. Impairment in $\mathrm{T}$ lymphocyte responses during early infection with the human immunodeficiency virus. J. Clin. Immunol. 1989, 9, 159-168.

30. Gruters, R. A.; Terpstra, F. G.; De Jong, R.; Van Noesel, C. J.; Van Lier, R. A.; Miedema, F. Selective loss of $\mathrm{T}$ cell functions in different stages of HIV infection. Early loss of anti-CD3-induced 
$\mathrm{T}$ cell proliferation followed by decreased anti-CD3-induced cytotoxic $\mathrm{T}$ lymphocyte generation in AIDS-related complex and AIDS. Eur. J. Immunol. 1990, 20, 1039-1044.

31. Roos, M. T.; Miedema, F.; Meinesz, A. P.; De Leeuw, N. A.; Pakker, N. G.; Lange, J. M.; Coutinho, R. A.; Schellekens, P. T. Low T cell reactivity to combined CD3 plus CD28 stimulation is predictive for progression to AIDS:correlation with decreased CD28 expression. Clin. Exp. Immunol. 1996, 105, 409-415.

32. McCloskey, T. W.; Cavaliere, T.; Bakshi, S.; Harper, R.; Fagin, J.; Kohn, N.; Pahwa, S. Immunophenotyping of $\mathrm{T}$ lymphocytes by three-color flow cytometry in healthy newborns, children, and adults. Clin. Immunol. Immunopathol. 1997, 84, 46-55.

33. Kovacs, J. A.; Lempicki, R. A.; Sidorov, I. A.; Adelsberger, J. W.; Herpin, B.; Metcalf, J. A.; Sereti, I.; Polis, M. A.; Davey, R. T.; Tavel, J.; Falloon, J.; Stevens, R.; Lambert, L.; Dewar, R.; Schwartzentruber, D. J.; Anver, M. R.; Baseler, M. W.; Masur, H., Dimitrov, D. S.; Lane, H. C. Identification of dynamically distinct subpopulations of $\mathrm{T}$ lymphocytes that are differentially affected by HIV. J. Exp. Med. 2001, 194, 1731-1741.

34. Mohri, H.; Perelson, A. S.; Tung, K.; Ribeiro, R. M.; Ramratnam, B.; Markowitz, M.; Kost, R.; Hurley, A.; Weinberger, L.; Cesar, D.; Hellerstein, M. K.; Ho, D. D. Increased turnover of T lymphocytes in HIV-1 infection and its reduction by antiretroviral therapy. J. Exp. Med. 2001, 194, 1277-1287.

35. Roos, M. T.; Miedema, F.; Koot, M.; Tersmette, M.; Schaasberg, W. P.; Coutinho, R. A.; Schellekens, P. T. T cell function in vitro is an independent progression marker for AIDS in human immunodeficiency virus-infected asymptomatic subjects. J. Infect. Dis. 1995, 171, 531-536.

36. Schellekens, P. T.; Roos, M. T.; De Wolf, F.; Lange, J. M.; Miedema, F. Low T cell responsiveness to activation via $\mathrm{CD} 3 / \mathrm{TCR}$ is a prognostic marker for acquired immunodeficiency syndrome (AIDS) in human immunodeficiency virus-1 (HIV-1)-infected men. J. Clin. Immunol. 1990, 10, 121-127.

37. Autran, B.; Carcelain, G.; Li, T. S.; Blanc, C.; Mathez, D.; Tubiana, R.; Katlama, C.; Debre, P.; Leibowitch, J. Positive effects of combined antiretroviral therapy on CD4+ T cell homeostasis and function in advanced HIV disease. Science 1997, 277, 112-116.

38. Pakker, N. G.; Roos, M. T.; van Leeuwen, R.; de Jong, M. D.; Koot, M.; Reiss, P.; Lange, J. M.; Miedema, F.; Danner, S. A.; Schellekens, P. T. Patterns of T-cell repopulation, virus load reduction, and restoration of T-cell function in HIV-infected persons during therapy with different antiretroviral agents. J. Acquir. Immune Defic. Syndr. Hum. Retrovirol. 1997, 16, 318-326.

39. Ballet, J. J.; Couderc, L. J.; Rabian-Herzog, C.; Duval-Roy, C.; Janier, M.; Danon, F.; Clauvel, J. P.; Seligmann, M. Impaired T-lymphocyte-dependent immune responses to microbial antigens in patients with HIV-1-associated persistent generalized lymphadenopathy. AIDS 1988, 2, 291-297.

40. Shearer, G. M.; Bernstein, D. C.; Tung, K. S.; Via, C. S.; Redfield, R.; Salahuddin, S. Z.; Gallo, R. C. A model for the selective loss of major histocompatibility complex self-restricted $\mathrm{T}$ cell immune responses during the development of acquired immune deficiency syndrome (AIDS). $J$. Immunol. 1986, 137, 2514-2521. 
41. Blazevic, V.; Sahgal, N.; Kessler, H. A.; Landay, A. L.; Shearer, G. M. T cell responses to recall antigens, alloantigen, and mitogen of HIV-infected patients receiving long-term combined antiretroviral therapy. AIDS Res. Hum. Retroviruses 2000, 16, 1887-1893.

42. Schellekens, P. T.; Roos, M. T.; De Wolf, F.; Lange, J. M.; Miedema, F. Low T-cell responsiveness to activation via $\mathrm{CD} 3 / \mathrm{TCR}$ is a prognostic marker for acquired immunodeficiency syndrome (AIDS) in human immunodeficiency virus-1 (HIV-1)-infected men. J. Clin. Immunol. 1990, 10, 121-127.

43. Messele, T.; Roos, M. T.; Hamann, D.; Koot, M.; Fontanet, A. L.; Miedema, F.; Schellekens, P. T.; Rinke de Wit, T. F. Nonradioactive techniques for measurement of in-vitro T-cell proliferation: alternatives to the $[(3) \mathrm{H}]$ thymidine incorporation assay. Clin. Diagn. Lab. Immunol. 2000, 7, 687692.

44. Clerici, M.; Stocks, N. I.; Zajac, R. A.; Boswell, R. N.; Lucey, D. R.; Via, C. S.; Shearer, G. M. Detection of three distinct patterns of $\mathrm{T}$ helper cell dysfunction in asymptomatic, human immunodeficiency virus-seropositive patients. Independence of CD4+ cell numbers and clinical staging. J. Clin. Invest. 1989, 84, 1892-1899.

45. Hofmann, B.; Jakobsen, K. D.; Odum, N.; Dickmeiss, E.; Platz, P.; Ryder, L. P.; Pedersen, C.; Mathiesen, L.; Bygbjerg, I. B.; Faber, V.; et al. HIV-induced immunodeficiency. Relatively preserved phytohemagglutinin as opposed to decreased pokeweed mitogen responses may be due to possibly preserved responses via CD2/phytohemagglutinin pathway. J. Immunol. 1989, 142, 18741880.

46. Rosenberg, Z. F.; Fauci, A.S. Immunopathogenic mechanisms of HIV infection: cytokine induction of HIV expression. Immunol. Today 1990, 11, 176-180.

(C) 2003 by MDPI (http://www.mdpi.org). 